\title{
THE TEACHER'S PERFORMANCE AND THE RELATIONSHIP OF AFFECTIVITY AND LEARNING FROM THE PERSPECTIVE OF PIAGET AND WALLON
}

\section{REVIEW ARTICLE}

DIAS, Adailton di Lauro ${ }^{1}$

DIAS, Adailton di Lauro. The teacher's performance and the relationship of affectivity and learning from the perspective of Piaget and Wallon. Revista Científica Multidisciplinar Núcleo do Conhecimento. Ano 04, Ed. 07, Vol. 09, pp. 6471. July 2019. ISSN: 2448-0959

\section{SUMMARY}

The study addresses the theme of the relationship of affectivity and learning. It cites the importance of the teacher's performance in this context. It addresses that affectivity, cognition and motivation collaborate in the development of learning the student through teacher mediation in daily school. It is based on theorists such as Piaget and Wallon. It has as general objective to understand the relationship between learning and affectivity from the perspective of Piaget and Wallon. It brings as a research problem: How can affectivity, cognition and motivation collaborate in the development of learning the student with the mediation of the teacher in the classroom? From the studies carried out, consideration is reached that, from Piaget's perspective, in his Piagetian theory, affectivity, cognition and motivation are necessary conditions in the constitution of intelligence and meaningful learning. In Wallon's view, in his theory called Wallonian, for learning, it is necessary to integrate between functional sets (affectivity, cognition, motricity and person). Thus, it is necessary to emphasize the importance of established relationships with the emotional aspects of

\footnotetext{
${ }^{1}$ Mestrando em Ciências da Educação (Grendal University). Especialista em Língua Inglesa (FIJ). Graduado em Letras (UNEB). Graduado em Português e Inglês pela Universidade Metropolitana de Santos - SP. Professor EBTT Port/Ing - IFRR.
} 
students in the teaching and learning process. And that relationships involving affectivity can affect each other in your behavior, helping you acquire knowledge more easily, making it smarter, driving it and motivating it to actions involving learning Significant. Thus, affectivity, cognition and motivation help in the development of learning students in daily school life.

Keywords: affection, learning, teacher, Piaget, Wallon.

\section{INTRODUCTION}

The study discusses the relationship between learning and affectivity, highlighting in this process, the importance of the teacher's performance in the classroom, demonstrating that his emotional state, as well as that of the students reflects positively or negatively in learning. It also brings the theme of affectivity, cognition and motivation as primary factors for the development and learning of the student, from the perspective of Piaget and Wallon.

The problem of study seeks to question: How can affectivity, cognition and motivation collaborate in the development of learning the student with the mediation of the teacher in the classroom ? To achieve the general objective that is configured in understanding the relationship between learning and affectivity from the perspective of Piaget and Wallon and also to respond to the problem of this study, bibliographic research was used. The reflections on the relationship between learning and the development of students motivated the construction of this work.

\section{THE AFFECTION, COGNITION AND MOTIVATION AS PRIMARY FACTORS FOR THE DEVELOPMENT AND LEARNING OF THE STUDENT}

Affectivity, cognition and motivation are essential factors for the development and learning of students in daily school, including to develop intelligence, since, 
(...) without affection, there would be no interest, no need, no motivation; and consequently, questions or problems would never be posed and there would be no intelligence. Affectivity is a necessary condition in the constitution of intelligence (PIAGET, 1992, p. 32).

Western education has as cultural heritage, the man's disconnection of his emotions, his thoughts, his own reality, resulting in the formation of weak individuals of spirit, energy and emotionally ignorant. This is, therefore, a fragmented view of man, which regrettably contributes to a rupture in human relations. However, these traditional dualisms of Western thought present in the history of traditional psychology were confronted and questioned by innovative theories with the aim of integrating, dialectically, cognition and affectivity, reason and emotion.

However, affectivity is indispensable for the intellectual development of children and adolescents, it drives them to act in the object of knowledge. "But affectivity is nothing without intelligence, which provides them with the means and clarifies the ends" (PIAGET, 1992, p.70). In this respect, intelligence acts in affective, considerably throughout the process of human existence, in which daily organization provides to active construction, elements favorable to personality formation.

Thus, it is possible to understand the relationships between affection and intelligence, this corresponds to the emotions that turn to the external world, oriented to the world of objects of study and observation. What is calling itself intelligence is the attention that the child and adolescent begin to direct to the components of the world around them, in order to try to understand how things work to adapt to them.

It is the reciprocal interrelationship of these two instances, affective and rational, that the formation and development of personality occurs, which here is understood as the product of the relationship that is constructed between the subject and the sociocultural environment, resulting in a unique being, Individual.

Piaget (1971) warned that, despite different in its nature, affectivity and cognition are inseparable, because in all symbolic and senseful actions they appear indissociated. 
He documented the effective behavior of action and thought as a cognitive aspect, through mental structures, and an affective aspect, through an energy, which is affectivity.

Vygotsky (2002) understands man as a being who has the ability to think, reason, deduce and abstract, but also as someone endowed with feelings, emotions, desires, imagination and sensitization to the outside world. Thus, you cannot analyze the feeling and reason separately. Rather, an analysis in its entirety makes sense, because it indicates favorable subsidies to possible solutions about existing problems. For "it demonstrates the existence of a dynamic system of meanings in which affective and intellectual come together" (VYGOTSKY, 2002, p. 7). However, it is indispensable to reinforce the meaning of the relationships that educators establish with the emotional aspects of students in the teaching and learning process.

Regarding emotions, Wallon (apud GALVÃO, 1995) says it has been from the beginning of life; defends it, as the first and strongest bond between individuals. At the beginning of its existence, the child gradually becomes a sociocognitive being when gradually constructing, a unique and particular view of its existence.

Wallon (apud GALVÃO, 1995) also states that affectivity appears when symbolic elements arise, that is, it manifests itself from contact with the other, makes it clear that affectivity involves a set of manifestations that encompasses feelings and emotions.

Within this consideration Galvão addresses in the text "expressiveness and emotions, according to Wallon's perspective" that:

Early on, through his impulsive gestures, contortions or body spasms, as well as the most primitive emotional expressions, such as crying or smiling, the human baby mobilizes the people of his surroundings in a kind of affective contagion. The adult interprets, accordingly, his values, desires and his expectations, the meaning of the baby's emotional expressions, being led to act according to his cultural parameters, desires 
and his individual beliefs, wrapped in the climate of contagion proper to these (GALVÃO, 1995, p. 74).

However, this way that the human baby has to express themselves are manifestations of pure emotion and provoke affective reactions that induce them to meet the needs of the child. In this sense, affectivity is the behavior capable of affecting the other, so that it drives it into action. The first form of affection lies in emotions, whose role is to unite individuals with each other by organic and intimate reactions in a global and undifferentiated way.

It is through this union that students when they arrive at school relate to each other, and gain significant advances in the cognitive sphere. With this, affective bonds expand and the teacher plays an important role in the development of students in the school context.

To adhere to motivational behavior to affective and cognitive aspects, it is worth mentioning that:

The development of intelligence undoubtedly allows motivation to be awakened by an increasing number of objects or situations. However, throughout this development, the basic principle remains the same: Affectivity is the driving spring of actions, and reason is at its service (LA TAILLE, 1992, p. 65).

Motivation, in turn, is an integral part of the teaching and learning process, is one of the considerable and essential elements to learn or accomplish something. All actions are moved by a motivational force. "Motivation is the driving force of the conduct. It is the internal condition that activates the individual and predisposes him to issue certain answers" (CORIA-SABINI, 2004, p. 83).

However, to learn or teach, a motivational driving force needs to occur. The absence of this day-to-day in educational practice both in the student and in the direction and in the faculty will impair the cognitive development of students. 


\subsection{AFFECTIVITY AND ITS RELATIONSHIP WITH LEARNING: THE PERFORMANCE OF THE TEACHER IN THE CLASSROOM}

Understanding the importance of teacher acting in the classroom, it is perceived that his emotional state, as well as that of the students reflects in learning. The teacher by showing affection in his actions, motivates the student to want to actively participate in his classes, perceiving the teacher as a friend always ready to help him and teach him.

For Oliveira and Chadwick (2001, p. 52),

The emotional and affective state of students influences their learning. Motivation is like a trigger that drives learning and establishes the conditions in which it occurs. Emotions play a strong role in learning at any stage of life. But they are particularly important in younger students, as the school situation is quite artificial in relation to their lives and not very compatible with their preferences.

The practice of an affective teacher will be to respect the learning rhythm of each student, because he has the sensitivity to perceive when or not to proceed with the content. A student may need more time to learn a certain discipline than their colleague, but it may also be faster in a discipline that has more affinity.

As Mendes (2017) asserts, it is necessary to reflect on pedagogical practice and teacher training. He states that continuing education reflects on the educator's role as a professional, however this training reflects, especially, in this professional as a person, because individuals end up being influenced by other people and by what they learn in decisions or choices and what will convey in everyday school. The theory chosen by this author is wallonian, whose primary point is to integrate functional sets - affectivity, cognition, motricity and the person and also the middle organism.

Thus, for Wallon (2007), this provides the understanding of the person in its entirety, understanding it not only from the perspective of one of the sets, but through the continuous integration between them. The study by Henri Wallon (1999) also 
emphasizes the environment in which the person is inserted, because both the individual and the person undergoes influence from each other. From this perspective, Wallon considers this element similarly important in his development process.

For the teacher to do a good work, aiming to reach as many students as possible, he needs to use various teaching techniques, adopting not only individual works, but also in pairs, group, etc. In addition, it is also important that teachers have a good relationship with other teachers in the school, to exchange information about students within each area of knowledge.

Within this context the teacher is in charge of promoting means that ensure motivation, in which it will lead to learning. Concerning this Coria-Sabini addresses:

Motivation has a cyclical aspect. First, there is a need that manifests itself through specific internal stimulation. Secondly, there are actions aimed at achieving a goal. Once this goal has been achieved, the relief and decrease in tension are followed. This relief is temporary and after some time the cycle resumes. A baby who is crying calms down after feeding. However, hours later hunger reappears and should be resatisfied (CORIA-SABINI, 2004, p. 84).

In fact this is what should happen in the classroom, the teacher must have strategies that motivate the student to act on the object of knowledge; when the student manages to draw his conclusions he will feel relieved. From this is the one who enters again the teacher bringing new problematizations and the student will once again go in search of the new knowledge. Each time the student reaches the proposed goal, it is up to the teacher to propose other challenges for the student to continue developing their potential.

Regarding the means or methodologies that the teacher uses to motivate his students do not come to the case, each works in a differentiated way, what matters is to work in a way that the student perceives learning as a personal achievement. As, for example, a student performs a certain activity he deemed unable to fulfill it, after the teacher 
offered him a toast challenging him to execute it. With this, the student can draw his conclusions that he is able to perform the activity without needing awards, but as a personal achievement.

However, the approaches of the authors cited, such as Piaget, Vygotsky and Wallon demonstrate how emotion alongside reason plays an essential role in student learning. According to them, the teacher's work cannot be restricted to mere memorization, but to feel and thrill with them. Unfortunately, this understanding of the relevance and role adopted by emotions in the teaching and learning process is rare among teachers, since the information that guides this idea is not passed on, and still taking into account that educational theories, such as technicalism, which underpin pedagogical practice, do not give due value to this emotional aspect of human development.

Saltini cites new paradigms in education, among them, it is worth mentioning what it says:

There will be a space and time within school when I can highlight my classmates, the world I live in, my ideas, fantasies, my discoveries, inventions, desires and dreams. These, emerging from our core, bind and make sense in the objects of the outside world, that is, each within himself builds its own bond, creating their symbols and values, as well as their special meaning, and is through these same meanings that the subject creates links between the inner world. From this and with this we must respect and create a pedagogical methodology that leads the subject to its full development (SALTINI, 2008, p. 31).

In this sense, the school is expected to become an environment of investigation, in which the subject of this process can express its forms of thought, its doubts and discoveries, so that it will improve its communicative capacity and expand, significantly, its insertion in space that develops the potential of students not only in the field of rationality, but also in the field of emotions. 
In short, Piaget, in addition to prioritizing the importance of biological maturation for the acquisition of learning, also considered the importance of interaction for the construction of knowledge. Vigotsky had his whole theory supported in the interaction between individual and middle. For the exchange between peers to be more effective, he highlighted the role of language for the expression of thought. Focusing on the relationship between affective and cognitive domains, Wallon created the theory of personality development, highlighting that this is formed between affectivity and cognition. In addition, he pointed out that affectivity is one of the oldest phases in development.

\section{CONCLUSION}

The study emphasizes the teacher's need to seek in the classroom, the integration between

affective and cognitive dimensions in the teaching and learning process, since affectivity and cognition are interconnected. In this context, the development of the precise affectivity of the elaborations carried out in the intelligence plan, and also, the development of intelligence needs the affective constructions.

Affectivity is still a broad field for research, it was noticed through this study that it is extremely important for the educational process and especially to establish a good relationship between teacher and student.

Unfortunately, during their development, children often grow up in an environment where people do not respect each other, living in hostility, where affectivity is absent. The tendency is for these children to become aggressive both in their families and at school. From the moment children become aggressive, difficulties will arise in social relationships. Therefore, it is necessary that the teacher knows how to deal with his students by demonstrating affection in his actions. 
However, the educator should be aware that it is not enough to be only affective for the student to learn. For this, the teacher must, first of all, be a researcher, concerned with his pedagogical practice, committed to his social and ethical function in his actions.

Affectivity is just a path to improving the teacher-student relationship, which will contribute to the school success of both. It is through affection at the time of dialogue between all members of the school community that doubts can be remedied, indiscipline can be circumvented and the student's desire to learn will be high and the learning achieved.

\section{REFERENCES}

CORIA-SABINI, Maria Aparecida. Psicologia do Desenvolvimento. 2. ed. São Paulo: Ática. 2004.

GALVÃO, Izabel. Henri Wallon: Uma concepção dialética do desenvolvimento infantil. Petrópolis, RJ: Vozes, 1995.

LA TAILLE, Yves de; OLIVEIRA, Marta Kohl de; DANTAS, Heloysa. Piaget, Vygotsky e Wallon: teorias psicogenéticas em discussão. 13. ed. São Paulo: Summus, 1992.

MENDES, Daniela Barros. Memórias afetivas: A constituição do professor na perspectiva de Henri Wallon. Sao Paulo: Loyola, 2017.

PIAGET, Jean. A equilibração das estruturas cognitivas. Problema central do desenvolvimento. Trad. Álvaro Cabral. Rio de Janeiro: Zahar, 1976.

. Desenvolvimento e aprendizagem. In: BRINGUIER, J.; PIANCELLA, J.R NESS. J.S.V., Org. In: Studying teaching. 2. ed. Prentice-Hall, 1971.

SALTINI, Cláudio J. P. Afetividade e Inteligência. 5. ed. - Rio de Janeiro: Wak Editora. 2008.

VYGOTSKY, Lev Semenovich. A formação social da mente: o desenvolvimento dos processos psicológicos superiores. 6. ed. São Paulo: Martins Fontes, 2002. 
WALLON, Henri. A evolução psicológica da criança. Lisboa: Edições 70, 1999. . Afetividade e aprendizagem - Contribuições de Henry Wallon. São Paulo: Edições Loyola, 2007.

Submitted: June, 2019.

Approved: July, 2019. 